\title{
Effect of heat stress on combining ability and heterosis in some bread wheat genotypes (Triticum aestivum L.)
}

\author{
Hassan, M. S. ${ }^{1}$, M. A. Ali ${ }^{1}$, M. N. T. Abd El-kader ${ }^{2}$ and I. G. Shahat ${ }^{1}$ \\ ${ }^{1}$ Department of Agronomy, Faculty of Agriculture, South Valley Univ., Qena, Egypt. \\ ${ }^{2}$ Wheat Research Departement, Field Crops Research Institute, ARC, Giza, Egypt.
}

\begin{abstract}
This research was undertaken to investigate 28 genotypes ( $21 \mathrm{~F}_{1}$-crosses and their seven parents) for heading date, plant height, 100-grain weight, and grain yield plant ${ }^{-1}$ under two planting dates (November $21^{\text {st }}$ as regular planting date and $21^{\text {st }}$ of December as late planting date) at El-Mattana, Agricultural Research Station, Luxor governorate, ARC, in2017/2018 and 2018/2019 growing seasons. Highly significant differences among genotypes, parents, crosses, and parents vs. crosses for all traits investigated under both sowing dates. Heat stress reduced estimates of all studied traits. Three parents $\left(\mathrm{P}_{1}, \mathrm{P}_{6}\right.$ and $\left.\mathrm{P}_{7}\right)$ and seven $\mathrm{F}_{1}$-hybrids $\left(\mathrm{P}_{1} \times \mathrm{P}_{2}, \mathrm{P}_{1} \times\right.$ $\mathrm{P}_{3}, \mathrm{P}_{1} \times \mathrm{P}_{5}, \mathrm{P}_{1} \times \mathrm{P}_{7}, \mathrm{P}_{4} \times \mathrm{P}_{7}, \mathrm{P}_{5} \times \mathrm{P}_{6}$, and $\mathrm{P}_{6} \times \mathrm{P}_{7}$ ) were highly tolerant, less susceptible (heat susceptibility index less than one), and less sensitive (less than one) for heat stress. Mean squares due to general (GCA) and specific (SCA) combining ability were highly significant for all studied traits. GCA/SCA ratios' magnitude were lower than one for all studied traits under both planting dates. The parents $\mathrm{P}_{5}$ and $\mathrm{P}_{7}$ were having significant adverse GCA effects for heading date, and the parents $\mathrm{P}_{2}$ and $\mathrm{P}_{4}$ showed significant positive effects for plant height and grain yield. The hybrid $\mathrm{P}_{2} \times \mathrm{P}_{7}$ observed significant positive heterosis in grain yield, 100-grain weight, and plant height, however, significantly negative in heading date in addition to satisfactory performance.
\end{abstract}

Keywords: Wheat; Combining ability; Heterosis; Heat stress

\section{Introduction}

Wheat (Triticum aestivum L.) is one of the essential strategic crops worldwide and in Egypt. Where in Egypt, all people approximately depend on wheat in their food. Despite the importance of wheat, national production is insufficient to meet the local demand due to the high population increase, especially in recent years. The local wheat production is about8.8million tons from 3.13 million feddan (FAO, 2018. On the other hand, delaying the sowing date exposes the wheat crop to high temperature sat the end of the growing duration. This could expose the wheat crop to some damages. Gribson and Paulsen (1999) reported that high-temperature stress is a major environmental factor limiting wheat yield. Every $1{ }^{\circ} \mathrm{C}$ increase over a mean temperature of $23^{\circ} \mathrm{C}$ reduces wheat yield by $10 \%$. Besides, delay in planting usually decreases individual plant growth and tillering potential (Shah et al., 2006). Decreasing grain yield in wheat due to the reduction in the number of spikes/unit area, the number of fertile spikes/plant, the number of grains/spike, and grain weight under high-temperature stress were also reported by Lobell et al. (2005). More 
breeding efforts are demanded to increase wheat production by improving its yielding ability under a suitable sowing date.

Inbreeding programs, understanding of combining ability and heterosis for parents and crosses are essential. By studying combining ability and estimating the degree of heterosis, evidence about the nature of the gene action, desirable parents, and essentialproductivity traits will emerge.

Several wheat studies indicated that general and specific combining ability effects for some parental genotypes and hybrids were positive and highly significant for grain yield (Hassan; 2015, Mwadzingeni et al.; 2017, Ahmed and Mohamed; 2009a, Nassar, 2013; Jaiswal et al.,2017; Sharma et al., 2019; Bajaniya et al., 2019; and Ali et al., 2020.

Estimates of average better parent heterosis for grain yield in wheat ranged from 1.03 to $47.60 \%$. Lower estimates were obtained with crosses of adapted parental genotypes (Ahmed and Mohamed, 2009a; Hassan, 2015 and Ali et al., 2020), while the high values most often resulted from studies which involved exotic germplasm or which were performed under environmental stress conditions (Ahmed and Mohamed, 2009a and Hassan, 2015).

Therefore, the current study was undertaken to identify the best combiner parental lines and their crosses based on their general and specific combining abilities for the studied traits under the two sowing dates, in addition, to determining the magnitude of heterosis expression at the two sowing dates.

\section{Materials and Methods}

\section{Experimental site:}

The current study was carried out during the 2017/2018 and 2018/2019 growing seasons at El-Mattana, Agricultural Research Station, Luxor governorate, ARC, Egypt. Minimum, maximum, and average monthly temperatures $\left({ }^{\circ} \mathrm{C}\right)$ at El-Mattana of 2018/2019 season are presented in Table 1. The genetic materials and diallel fashion:

The genetic materials used in this study included seven divergent bread wheat parents (Triticum aestivum L.), Sakha-94 $\left(\mathrm{P}_{1}\right)$, Misr-2 $\left(\mathrm{P}_{2}\right)$, Sids-1 $\left(\mathrm{P}_{3}\right)$, Gimmaza-9 $\left(\mathrm{P}_{4}\right)$, Giza-168 $\left(\mathrm{P}_{5}\right)$, Shandaweel-1 $\left(\mathrm{P}_{6}\right)$, and Sids-12 $\left(\mathrm{P}_{7}\right)$. These genotypes were planted in the first season under field conditions on three planting dates November $23^{\text {rd }}$, December $3^{\text {rd, }}$ and December $14^{\text {th, }}$ to avoid differences in the flowering time and secure enough pollen grains to make hybrids with enough seeds. Each parent was sown inone line, three meters long; the distance between the lines is $50 \mathrm{~cm}$. These genotypes were mated in a diallel fashion without reciprocals to obtain $\mathrm{F}_{1}$ - hybrid seeds.

\section{Evaluation trials:}

In the second season, two experiments were conducted; the $1^{\text {st }}\left(\mathrm{D}_{1}\right)$ on November $21^{\text {st }}$ (normal planting date) and the $2^{\text {nd }}\left(D_{2}\right)$ on $21^{\text {st }}$ of December (late planting date). Each experiment included the 7 parents and their $21 \mathrm{~F}_{1}$-hybrids and was conducted with three replicates in a Randomized Complete Block Design (RCBD). Each of the parental and $\mathrm{F}_{1}$ crosses was represented by two rows of plants per replicate. A single row plot $3 \mathrm{~m}$ long spaced $30 \mathrm{~cm}$ apart and plant spaced $10 \mathrm{~cm}$ within each row represented each genotype. The agricultural practices were followed as recommended for wheat production at two planting dates. 
Table 1. Minimum, maximum, and average monthly temperature $\left({ }^{\circ} \mathrm{C}\right)$ at El-Mattana Station from sowing to physiological maturity during the 2018/2019 season

\begin{tabular}{|c|c|c|c|c|}
\hline \multicolumn{2}{|c|}{ Season } & \multicolumn{3}{|c|}{$2018 / 2019$} \\
\hline Month & Day & Maximum & Minimum & Average \\
\hline Nov. & $22-30$ & 24.3 & 13.1 & 18.7 \\
\hline \multicolumn{2}{|c|}{ Average } & 24.3 & 13.1 & 18.7 \\
\hline \multirow{3}{*}{ Dec. } & $1-10$ & 23.3 & 11.0 & 17.2 \\
\hline & $11-20$ & 23.2 & 8.7 & 16.0 \\
\hline & $21-31$ & 21.7 & 8.9 & 15.3 \\
\hline \multicolumn{2}{|c|}{ Average } & 22.7 & 9.5 & 16.1 \\
\hline \multirow{3}{*}{ January } & $1-10$ & 20.1 & 6.4 & 13.3 \\
\hline & $11-20$ & 18.7 & 6.2 & 12.5 \\
\hline & $21-31$ & 19.5 & 4.7 & 12.1 \\
\hline \multicolumn{2}{|c|}{ Average } & 19.4 & 5.8 & 16.6 \\
\hline \multirow{3}{*}{ February } & $1-10$ & 23.4 & 7.7 & 15.6 \\
\hline & $11-20$ & 24.5 & 10.5 & 17.5 \\
\hline & $21-28$ & 19.5 & 7.6 & 13.6 \\
\hline \multicolumn{2}{|c|}{ Average } & 22.5 & 8.6 & 15.5 \\
\hline \multirow{3}{*}{ March } & $1-10$ & 24.5 & 9.4 & 17.0 \\
\hline & $11-20$ & 28.0 & 11.9 & 20.0 \\
\hline & $21-31$ & 28.0 & 14.5 & 21.3 \\
\hline \multicolumn{2}{|c|}{ Average } & 26.8 & 11.9 & 19.4 \\
\hline \multirow{3}{*}{ April } & $1-10$ & 30.9 & 15.8 & 23.4 \\
\hline & $11-20$ & 32.1 & 16.5 & 24.3 \\
\hline & $21-30$ & 34.9 & 18.1 & 26.5 \\
\hline \multicolumn{2}{|c|}{ Average } & 32.6 & 16.8 & 24.7 \\
\hline May & $1-15$ & 40.1 & 23.1 & 31.6 \\
\hline \multicolumn{2}{|c|}{ Average } & 40.1 & 23.1 & 31.6 \\
\hline
\end{tabular}

Meteorological Authority at El-Mattana, Luxor.

\section{Measurements:}

For each genotype, ten guarded plants were taken randomly from each replicate to registering observation on days to heading (day), plant height (cm.), 100grain weight $(\mathrm{g})$, and grain yield/plant $(\mathrm{g})$.

\section{Statistical procedures}

\section{1- Mean performance and analysis of variance:}

Analysis of variance was performed according to Gomez and Gomez (1984) for a single experiment.

Revised least significant differences (LSD') at 0.05 levels of probability were used to compare means according to ElRawi and Khalafalla (1980).

- Heat tolerance, heat susceptibility index, and sensitivity.

- Heat tolerance (HT) computed according to the following equation: $\mathrm{HT}=\frac{\text { Grain yield for individual genotype under stress conditions (D2) }}{\text { Grain yield for the same genotype under normal conditions (D1) }}$

Heat susceptibility index (HSI) was calculated according to Fisher and Maurer (1978) method. The sensitivity was computed according to Falconer (1990). To calculate each HSI and sensitivity for parental genotypes and their crosses, the 
yield means of parents and crosses were used, respectively.

\section{2- Combining ability analysis}

General (GCA) and specific (SCA) combining ability variances and their effects were calculated using a standard method for analysis of conflict in a

\section{Results and Discussion}

\section{A-Mean performance of genotypes Analysis of variance}

There were highly significant differences among genotypes and their components (parents, crosses, and P vs. C) for all investigated traits under both sowing dates, indicating high genetic diversity among them (Table 2).

\section{Days to heading}

Data in Table 3 showed that the average days from sowing to heading for parental genotypes ranged from 77.33 for $\mathrm{P}_{5}$ to 90.67 for $\mathrm{P}_{2}$ at normal sowing date, but is reduced to 77.00 and 84.33 days for the same genotypes at late sowing date. The average overall parents were 85.29 days at normal sowing date but are reduced to 80.48 days under late sowing date, indicating a reduction of $5.64 \%$ in days to heading due to heat stress. The $\mathrm{F}_{1}$-crosses performance ranged from 89.33 for the cross $\mathrm{P}_{1} \times \mathrm{P}_{2}$ to 74.33 days for the cross $\mathrm{P}_{1} \times \mathrm{P}_{5}$ under early planting date but is reduced to 81.33 for the cross $\mathrm{P}_{1} \times \mathrm{P}_{4}$ and 65.00 days for the cross $\mathrm{P}_{1}$ $\times \mathrm{P}_{5}$ under late planting date. The average number of days to the heading of all $\mathrm{F}_{1}$ crosses reduced from 83.79 to 76.43 days at regular and late dates, respectively, showing an $8.78 \%$ reduction in heading time. The results showed that $\mathrm{P}_{5}$ possesses genes for randomized complete block design according to Griffing (1956), method II model I.

\section{3- Heterosis:}

Heterosis was calculated as the percentage of deviation of $\mathrm{F}_{1}$ 's mean from the mean better parent, according to Bahatt (1971).

earliness where all of its crosses were early either under regular or late planting dates. In this connection, the crosses were earlier and higher in reduction\% than parents from early to late sowing dates. The delaying date of planting reduced the number of days from sowing to heading. In this line, with applying late sowing, significant shortening of the period of ear growth and flowering period was noticed because starting the flowering stage when the atmospheric temperature starts rising (Saini et al., 1986). Also, these results agree with those reported by Ahmed and Mohamed (2009a), Hassan (2015), Jaiswal et al. (2017), Ahmed et al. (2017), Sharma et al. (2019), Bajaniya et al. (2019), and Ali et al. (2020).

\section{Plant height}

Average plant height for parental genotypes varied from 88.8 for $\mathrm{P}_{5}$ to 104.8 $\mathrm{cm}$ for $\mathrm{P}_{2}$ under favorable sowing date, while it decreased to 82.5 and $97.0 \mathrm{~cm}$ for the same parents under unfavorable sowing date (Table 3). The average of all parents was $98.9 \mathrm{~cm}$ at early date, but it decreased to $90.4 \mathrm{~cm}$ at a late date, indicating an $8.59 \%$ reduction in plant height due to delaying the sowing date. Mean plant height for $\mathrm{F}_{1}$-hybrids varied from 99.2 for $\mathrm{P}_{4} \times \mathrm{P}_{6}$ to $106.2 \mathrm{~cm}$ for $\mathrm{P}_{2} \times \mathrm{P}_{6}$ at normal 
Table 2. Mean squares from ANOVA combined the $F_{1}$-hybrids of bread wheat genotypes under normal $(\mathrm{N})$ and late (L) sowing dates

\begin{tabular}{|c|c|c|c|c|c|c|c|c|c|}
\hline \multirow[t]{2}{*}{ S.O.V } & \multirow[t]{2}{*}{ df } & \multicolumn{2}{|c|}{$\begin{array}{c}\text { Days to } \\
\text { heading (days) } \\
5.71\end{array}$} & \multicolumn{2}{|c|}{$\begin{array}{l}\text { Plant height } \\
(\mathrm{cm})\end{array}$} & \multicolumn{2}{|c|}{$\begin{array}{l}\text { 100-grain } \\
\text { weight (g) }\end{array}$} & \multicolumn{2}{|c|}{$\begin{array}{c}\text { Grain } \\
\text { yield/plant (g) }\end{array}$} \\
\hline & & $\mathrm{N}$ & $\mathrm{L}$ & $\mathrm{N}$ & $\mathrm{L}$ & $\mathrm{N}$ & $\mathrm{L}$ & $\mathrm{N}$ & $\mathrm{L}$ \\
\hline Reps & 2 & 2.61 & 7.75 & $20.76^{* *}$ & $17.79^{*}$ & 0.15 & 0.20 & 6.86 & $7.73^{*}$ \\
\hline Genotypes (G) & 27 & $61.62^{* *}$ & $69.47^{* *}$ & $48.82^{* *}$ & $63.62^{* *}$ & $1.02^{* *}$ & $0.62^{* *}$ & $43.21^{* *}$ & $18.67^{* *}$ \\
\hline Parents (P) & 6 & $78.08^{* *}$ & $20.98^{* *}$ & $139.22^{* *}$ & $97.10^{* *}$ & $0.73^{* *}$ & $0.38^{* *}$ & $15.38^{* *}$ & $10.23^{* *}$ \\
\hline Crosses (C) & 20 & $58.08^{* *}$ & $74.38^{* *}$ & $11.76^{* *}$ & $40.41^{* *}$ & $0.75^{* *}$ & $0.57^{* *}$ & $42.02^{* *}$ & $19.31^{* *}$ \\
\hline P vs. C & 1 & $33.59^{* *}$ & $262.10^{* *}$ & $247.58^{* *}$ & $326.86^{* *}$ & $8.04^{* *}$ & $3.11^{* *}$ & $233.94^{* *}$ & $56.38^{* *}$ \\
\hline GCA & 6 & $43.70^{* *}$ & $22.54^{* *}$ & $27.45^{* *}$ & $43.14^{* *}$ & $0.24^{*}$ & $0.16^{*}$ & $27.59^{* *}$ & $5.01^{*}$ \\
\hline SCA & 21 & $11.84^{* *}$ & $22.26^{* *}$ & $11.77^{* *}$ & $12.88^{* *}$ & $0.36^{* *}$ & $0.21^{* *}$ & $9.32^{* *}$ & $6.33^{* *}$ \\
\hline Error & 54 & 2.21 & 6.07 & 2.50 & 3.80 & 0.11 & 0.07 & 3.78 & 1.85 \\
\hline$\Sigma \mathrm{g}_{\mathrm{i}}^{2} / \Sigma \mathrm{S}_{\mathrm{ij}}{ }^{2}$ & - & 0.29 & 0.001 & 0.14 & 0.26 & -0.04 & -0.03 & 0.23 & -0.02 \\
\hline
\end{tabular}

*, **; Significant at 0.05 and 0.01 levels of probability, respectively.

planting date, while it reduced to 89.5 for $\mathrm{P}_{3}$ $\times \mathrm{P}_{5}$ to $101.2 \mathrm{~cm}$ for $\mathrm{P}_{2} \times \mathrm{P}_{3}$ at a late date (Table 3). The average plant height of all $\mathrm{F}_{1-}$ hybrids decreased from $102.9 \mathrm{~cm}$ at the desired date to $94.9 \mathrm{~cm}$ at the undesirable date, reflecting a reduction of $7.77 \%$ in plant height. The cross $\mathrm{P}_{2} \times \mathrm{P}_{3}$ was the tallest one under normal andlate planting dates. This result may be because $\mathrm{P} 2$ is the tallest parent and passed its target genes to this cross (Table 3). These results are in line with those obtained by El-Beially and ElSayed (2002), Ahmadi et al. (2003), Ahmed and Mohamed (2009a), Wajid et al. (2011), Ezatollah et al. (2013),Hassan (2015), Hassan (2016), Jaiswal et al. (2017), Ahmed et al. (2017), Sharma et al. (2019), Bajaniya et al. (2019) and Ali et al. (2020).

\section{0-grain weight}

For 100-grain weight, the average of parental genotypes exhibited that the heavier averages were 5.33 and $4.00 \mathrm{~g}$ for $\mathrm{P}_{1}$. The lighter averages were 3.67 and 2.89 $\mathrm{g}$ for $\mathrm{P}_{3}$ normal and late planting dates, respectively. The average of all parents for
100 -grain weight decreased from 4.53 at a normal date to $3.46 \mathrm{~g}$ at a late planting date, indicating a $23.62 \%$ reduction in 100 -grain weight (Table 3 ). The heavier averages of 100-grain weight for $\mathrm{F}_{1}$-hybrids were 6.00 and $5.00 \mathrm{~g}$ for $\mathrm{P}_{5} \times \mathrm{P}_{7}$, but the lighter averages were 3.67 for $\mathrm{P}_{3} \times \mathrm{P}_{5}$ and $3.33 \mathrm{~g}$ for $\mathrm{P}_{2} \times \mathrm{P}_{4}$ and $\mathrm{P}_{2} \times \mathrm{P}_{5}$ under early and late sowing dates, respectively. The average of all $\mathrm{F}_{1}$-hybrids for 100 -grain weight was 5.17 and $3.90 \mathrm{~g}$ under normal and late planting dates, respectively (Table 3 ). The $\mathrm{F}_{1}$-hybrids were heavier and higher in reduction\% than parents from early to late sowing dates. 100-grain weight overall genotypes were decreased byheat stress; the decrease reached to $26.55 \%$ from the normal planting date. This reduction may be due to the high-temperature effects during the grain filling period (Table 1). These results agree with those obtained by Samra et al. (1989), who showed that high temperature during the month of maturity might have a forced effect on the maturity of the late plant crop and lower grain weight. These findings are in line with those reported by El-Beially and El-Sayed 
Table 3. Mean performance of the eight parents and $F_{1}$ 's hybrids for days to heading, plant height, and 100-grain weight under normal $(\mathrm{N})$ and late (L) sowing dates

\begin{tabular}{|c|c|c|c|c|c|c|c|c|c|c|c|}
\hline \multirow[t]{2}{*}{ Genotypes } & \multicolumn{2}{|c|}{$\begin{array}{l}\text { Days to } \\
\text { heading } \\
\text { (days) }\end{array}$} & \multicolumn{2}{|c|}{$\begin{array}{l}\text { Plant height } \\
(\mathrm{cm})\end{array}$} & \multicolumn{2}{|c|}{$\begin{array}{l}\text { 100-grain } \\
\text { weight } \\
\text { (gm) }\end{array}$} & \multicolumn{5}{|c|}{$\begin{array}{l}\text { Grain yield/plant } \\
\text { (gm) }\end{array}$} \\
\hline & $\mathrm{N}$ & $\mathrm{L}$ & $\mathrm{N}$ & $\mathrm{L}$ & $\mathrm{N}$ & $\mathrm{L}$ & $\mathrm{N}$ & $\mathrm{L}$ & HT & HSI & $\mathrm{S}$ \\
\hline$P_{1}$ & 88.67 & 82.67 & 102.2 & 92.2 & 5.33 & 4.00 & 19.03 & 16.57 & 0.87 & 0.75 & 0.70 \\
\hline $\mathrm{P}_{2}$ & 90.67 & 84.33 & 104.8 & 97.0 & 4.67 & 3.33 & 21.43 & 17.60 & 0.82 & 1.03 & 1.09 \\
\hline $\mathrm{P}_{3}$ & 86.67 & 80.67 & 104.7 & 94.8 & 3.67 & 2.89 & 21.53 & 17.27 & 0.80 & 1.14 & 1.22 \\
\hline $\mathrm{P}_{4}$ & 89.33 & 81.00 & 103.0 & 94.7 & 4.67 & 3.67 & 24.23 & 17.33 & 0.72 & 1.65 & 1.97 \\
\hline $\mathrm{P}_{5}$ & 77.33 & 77.00 & 88.8 & 82.5 & 4.17 & 3.33 & 18.77 & 12.97 & 0.69 & 1.79 & 1.66 \\
\hline $\mathrm{P}_{6}$ & 84.33 & 80.67 & 98.8 & 87.2 & 5.00 & 3.33 & 19.10 & 18.93 & 0.99 & 0.05 & 0.05 \\
\hline $\mathrm{P}_{7}$ & 80.00 & 77.00 & 90.0 & 84.3 & 4.17 & 3.67 & 17.63 & 16.60 & 0.94 & 0.34 & 0.29 \\
\hline Mean (p) & 85.29 & 80.48 & 98.9 & 90.4 & 4.53 & 3.46 & 20.25 & 16.75 & - & - & - \\
\hline $\mathrm{P}_{1} \times \mathrm{P}_{2}$ & 89.33 & 79.67 & 104.3 & 97.8 & 5.33 & 4.00 & 24.27 & 17.63 & 0.73 & 0.71 & 0.72 \\
\hline $\mathrm{P}_{1} \times \mathrm{P}_{3}$ & 86.33 & 77.33 & 101.5 & 99.7 & 5.00 & 3.67 & 24.63 & 14.53 & 0.59 & 1.07 & 1.09 \\
\hline $\mathrm{P}_{1} \times \mathrm{P}_{4}$ & 88.67 & 81.33 & 103.0 & 96.5 & 5.00 & 3.67 & 20.37 & 18.90 & 0.93 & 0.19 & 0.16 \\
\hline $\mathrm{P}_{1} \times \mathrm{P}_{5}$ & 74.33 & 65.00 & 103.5 & 94.5 & 5.00 & 4.00 & 20.40 & 12.50 & 0.61 & 1.01 & 0.85 \\
\hline $\mathrm{P}_{1} \times \mathrm{P}_{6}$ & 86.33 & 80.00 & 101.3 & 95.8 & 5.67 & 4.00 & 20.87 & 15.50 & 0.74 & 0.67 & 0.58 \\
\hline $\mathrm{P}_{1} \times \mathrm{P}_{7}$ & 75.33 & 66.00 & 101.0 & 91.0 & 5.33 & 4.00 & 30.63 & 13.63 & 0.44 & 1.45 & 1.84 \\
\hline $\mathrm{P}_{2} \times \mathrm{P}_{3}$ & 87.33 & 76.67 & 106.5 & 101.2 & 5.67 & 4.00 & 27.13 & 15.30 & 0.56 & 1.14 & 1.28 \\
\hline $\mathrm{P}_{2} \times \mathrm{P}_{4}$ & 88.67 & 77.67 & 105.3 & 100.0 & 5.33 & 3.33 & 22.93 & 13.83 & 0.60 & 1.04 & 0.98 \\
\hline $\mathrm{P}_{2} \times \mathrm{P}_{5}$ & 80.33 & 67.33 & 102.2 & 98.2 & 5.00 & 3.33 & 27.73 & 15.27 & 0.55 & 1.17 & 1.35 \\
\hline $\mathrm{P}_{2} \times \mathrm{P}_{6}$ & 84.33 & 80.67 & 106.2 & 100.7 & 4.67 & 3.67 & 25.10 & 15.03 & 0.60 & 1.05 & 1.09 \\
\hline $\mathrm{P}_{2} \times \mathrm{P}_{7}$ & 79.67 & 69.00 & 104.2 & 94.5 & 5.33 & 4.00 & 29.00 & 15.13 & 0.52 & 1.25 & 1.5 \\
\hline $\mathrm{P}_{3} \times \mathrm{P}_{4}$ & 88.33 & 77.67 & 104.3 & 95.2 & 5.00 & 4.00 & 23.97 & 13.07 & 0.55 & 1.19 & 1.18 \\
\hline $\mathrm{P}_{3} \times \mathrm{P}_{5}$ & 79.33 & 77.33 & 103.0 & 89.5 & 3.67 & 3.67 & 29.70 & 13.60 & 0.46 & 1.42 & 1.74 \\
\hline $\mathrm{P}_{3} \times \mathrm{P}_{6}$ & 85.67 & 79.00 & 103.5 & 91.5 & 5.33 & 4.33 & 25.30 & 11.57 & 0.46 & 1.42 & 1.49 \\
\hline $\mathrm{P}_{3} \times \mathrm{P}_{7}$ & 79.67 & 79.33 & 99.3 & 89.8 & 5.33 & 3.67 & 28.40 & 15.03 & 0.53 & 1.23 & 1.45 \\
\hline $\mathrm{P}_{4} \times \mathrm{P}_{5}$ & 79.67 & 78.33 & 103.2 & 90.3 & 5.00 & 3.67 & 21.23 & 12.00 & 0.57 & 1.14 & 0.99 \\
\hline $\mathrm{P}_{4} \times \mathrm{P}_{6}$ & 85.67 & 80.00 & 99.2 & 92.3 & 5.33 & 3.67 & 25.63 & 18.13 & 0.71 & 0.76 & 0.81 \\
\hline $\mathrm{P}_{4} \times \mathrm{P}_{7}$ & 85.33 & 79.33 & 102.2 & 93.8 & 5.67 & 5.00 & 17.93 & 15.03 & 0.84 & 0.42 & 0.31 \\
\hline $\mathrm{P}_{5} \times \mathrm{P}_{6}$ & 84.67 & 78.67 & 100.5 & 92.5 & 5.33 & 3.67 & 19.30 & 11.20 & 0.58 & 1.1 & 0.88 \\
\hline $\mathrm{P}_{5} \times \mathrm{P}_{7}$ & 84.67 & 77.33 & 103.7 & 96.5 & 6.00 & 5.00 & 19.13 & 13.53 & 0.71 & 0.76 & 0.61 \\
\hline $\mathrm{P}_{6} \times \mathrm{P}_{7}$ & 86.00 & 77.33 & 103.0 & 92.3 & 4.67 & 3.67 & 20.25 & 16.75 & 0.83 & 0.45 & 0.38 \\
\hline Mean (C) & 83.79 & 76.43 & 102.90 & 94.93 & 5.17 & 3.90 & 24.10 & 14.86 & - & - & - \\
\hline Mean $(G)$ & 84.17 & 77.44 & 100.9 & 92.7 & 5.01 & 3.68 & 22.17 & 15.81 & - & - & - \\
\hline $\mathrm{LSD}_{0.05}^{\prime}(\mathrm{P})$ & 1.94 & 5.83 & 2.46 & 3.71 & 0.32 & 0.50 & 3.47 & 3.65 & - & - & - \\
\hline $\operatorname{LSD}_{0.05}^{\prime}(\mathrm{C})$ & 2.05 & 4.27 & 2.69 & 3.03 & 0.57 & 0.39 & 3.09 & 2.08 & - & - & - \\
\hline $\operatorname{LSD}_{0.05}^{\prime}(\mathrm{G})$ & 2.21 & 4.42 & 2.36 & 3.02 & 0.49 & 0.38 & 3.02 & 2.11 & - & - & - \\
\hline Red.\% of $\mathrm{P}$ & \multicolumn{2}{|c|}{5.64} & \multicolumn{2}{|c|}{8.59} & \multicolumn{2}{|c|}{23.62} & \multicolumn{2}{|c|}{17.28} & \multicolumn{2}{|c|}{ - } & - \\
\hline Red.\% of C & \multicolumn{2}{|c|}{8.78} & \multicolumn{2}{|c|}{7.77} & \multicolumn{2}{|c|}{24.56} & \multicolumn{2}{|c|}{38.34} & \multicolumn{2}{|c|}{ - } & - \\
\hline Red. $\%$ of G & \multicolumn{2}{|c|}{8.00} & \multicolumn{2}{|c|}{8.13} & \multicolumn{2}{|c|}{26.55} & \multicolumn{2}{|c|}{28.69} & \multicolumn{2}{|c|}{ 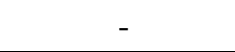 } & - \\
\hline
\end{tabular}

(2002), Darwish et al.(2006), Ahmed and Mohamed (2009a), Hassan (2015), Jaiswal et al. (2017), Ahmed et al. (2017), Sharma et al. (2019), Bajaniya et al. (2019), and Ali et al. (2020).

Grain yield plant ${ }^{-1}$ 
The average grain yield/plant for parental genotypes indicated that the higher averages were 24.23 for $\mathrm{P}_{4}$ and $18.93 \mathrm{~g}$ for $\mathrm{P}_{6}$. Still, the lower averages were 17.63for $\mathrm{P}_{7}$ and $12.97 \mathrm{~g}$ for $\mathrm{P}_{5}$ under normal and late planting dates, respectively. The averages of grain yield plant ${ }^{-1}$ overall parents were 20.25 and 16.75 gm under normal and late planting dates, respectively (Table 3). Mean of grain yield plant $^{-1}$ for $F_{1}$-hybrids exhibited that the higher averages were 30.63 for $\mathrm{P}_{1} \times \mathrm{P}_{7}$ and $18.90 \mathrm{~g}$ for $\mathrm{P}_{1} \times \mathrm{P}_{4}$, but the lower averages were 17.93 for $\mathrm{P}_{4} \times \mathrm{P}_{7}$ and $11.20 \mathrm{~g}$ for $\mathrm{P}_{5} \times \mathrm{P}_{6}$ under normal and late planting dates, respectively. Average of grain yield plant ${ }^{-1}$ for $\mathrm{F}_{1}$-hybrids was 24.10 and $14.86 \mathrm{~g}$ under normal and late planting dates. Grain yield plant $^{-1}$ overall genotypes decreased by heat stress; the decreased value reached $28.69 \%$ from the normal planting date. This reduction may be

\section{B-Combining ability}

\section{Analysis of variance}

From the results in Table 2, mean squares due to GCA and SCA were significant or highly significant for all studied traits under normal and late planting dates. This reveals the importance of the additive and non-additive effects for inheritance of these studied traits.

GCA/SCA ratios' magnitude was lower than one for 100-grain weight and grain yield plant ${ }^{-1}$ under both planting dates, except grain yield plant $^{-1}$ under normal planting date. This indicates that the nonadditive (dominance, over dominance and epistasis) effects seem more important than additive effects in these traits' inheritance mechanisms. The preponderance of nonadditive variance in expression of these traits in wheat have also been reported by due to the negative effect of high temperature on grain filing rate. These results are in line with those obtained by Dencic et al. (2000), Hoffman and Burucs (2005), Mohamed (2007), Ahmed and Mohamed (2009a), Hassan (2015), Hassan (2016), Jaiswal et al. (2017), Ahmed et al. (2017), Sharma et al. (2019), Bajaniya et al. (2019) and Ali et al. (2020).

\section{Heat tolerance, heat susceptibility index, and sensitivity}

Three parents $\left(\mathrm{P}_{1}, \mathrm{P}_{6}\right.$ and $\left.\mathrm{P}_{7}\right)$ and three $\mathrm{F}_{1}$-hybrids $\left(\mathrm{P}_{1} \times \mathrm{P}_{4}, \mathrm{P}_{4} \times \mathrm{P}_{7}\right.$ and $\mathrm{P}_{6} \times$ $\mathrm{P}_{7}$ ) had highly tolerant for heat stress, heat susceptibility index less than one (less susceptible) and also gave values less than one (less sensitive) insensitivity test, since they gave intermediate yield compared to yield under normal ones.

Dhadhal et al. (2006), Lohithaswa et al. (2013), Barot et al. (2014), Pansuriya et al. (2014), Ahmed et al. (2017), Ahmed and Mohamed (2009a) and Bajaniya et al. (2019) for 100-grain weight; Sharma and Garg (2005), Vanpariya et al. (2006), Singh et al. (2013), Ahmed and Mohamed (2009a) and Bajaniya et al. (2019) for grain yield per plant. Because of these studies, it could be concluded that grain yield is a complex character compared to its components. Thus, as the quantitative character becomes complex, and the contribution of nonadditive gene action would be more.The present finding was partially in harmony with those obtained by Ahmed and Mohamed (2009a), Jaiswal et al. (2017), Sharma et al. (2019), and Ali et al. (2020), which indicated that GCA was more important than SCA in the inheritance of most studied traits. Nassar (2013) and 
Hassan (2015) stated that both additive and non-additive variation had an important role in controlling most traits' inheritance.

\section{Combining ability effects}

\section{General combining ability effects:}

Mean values and additive gene action for characters under consideration are usually considered the primary criteria for selecting favorable parents. Genetically, the GCA effect is associated with additive gene action. A highly significant negative GCA value for the traitof days to heading was obtained for the parental genotypes $\mathrm{P}_{5}$ and $\mathrm{P}_{7}$ under normal and late sowing dates, which contributed to improving the duration to heading in their crosses (Table 4). Two parents $\left(\mathrm{P}_{2}\right.$ and $\left.\mathrm{P}_{4}\right)$ recorded significantly positive GCA effects for plant height under different sowing dates, contributing to increasedplant high in their crosses.

For 100-grain weight, the parents $\mathrm{P}_{1}$ and $\mathrm{P}_{7}$ displayed significantly positive GCA effects under normal and late sowing dates, respectively. These parents are considered to be good combiners for grain weight.

Parental genotypes such as $\mathrm{P}_{2}$ and $\mathrm{P}_{4}$ had positive and highly significant GCA effects for grain yield/plant under normal and late sowing dates, indicating that they would be good parents of high grain yielding offspring. The parents selected for a particular trait were not always acceptable for other traits. For example, $\mathrm{P}_{2}$ and $\mathrm{P}_{4}$ had high mean grain yield and highly significant positive GCA effects, but its longer duration to heading under different environments is not desirable. Also, $\mathrm{P}_{5}$ and $\mathrm{P}_{7}$ had a shorter duration toheading and highly significant negative GCA effects, but it exhibited low mean grain yield, which isnot desirable. These results are in harmony with those obtained by Ali (2006), Ahmed and Mohamed (2009a), Hassan (2015), and Ali et al. (2020).

\section{Specific combining ability effects:}

Superior hybrids were selected based on both hybrid performance and SCA effects. Among the $21 \mathrm{~F}_{1}$-hybrids, four crosses $\left(\mathrm{P}_{1} \times \mathrm{P}_{5}, \mathrm{P}_{1} \times \mathrm{P}_{7}, \mathrm{P}_{2} \times \mathrm{P}_{5}\right.$, five and $\mathrm{P}_{2}$ $\times \mathrm{P}_{7}$ ) showed highly significant negative SCA effects for days to heading under different sowing dates (Table 4). These crosses were considered the best combinations for earliness.

Five crosses; $\mathrm{P}_{1} \times \mathrm{P}_{5}, \mathrm{P}_{2} \times \mathrm{P}_{6}, \mathrm{P}_{2} \times$ $\mathrm{P}_{7}, \mathrm{P}_{5} \times \mathrm{P}_{7}$, and $\mathrm{P}_{6} \times \mathrm{P}_{7}$, exhibited highly significant positive SCA effects for plant height in both sowing dates. This indicates that these hybrids were considered the best combinations for tallness.

The hybrids $\mathrm{P}_{2} \times \mathrm{P}_{3}, \mathrm{P}_{2} \times \mathrm{P}_{7}, \mathrm{P}_{3} \times \mathrm{P}_{6}$, and $\mathrm{P}_{5} \times \mathrm{P}_{7}$ had significantly positive SCA effects for 100-grain weight in early and late sowing dates.

One cross only, $\mathrm{P}_{2} \times \mathrm{P}_{7}$, showed significant positive SCA effects for grain yield and gave the highest grain yield in their performance under early and late sowing dates (Table 4). Considering the two main traits, earliness and grain yield, the cross $\mathrm{P}_{2}$ $\times \mathrm{P}_{7}$ could be selected as a good hybrid combination. It exhibited a highly significant positive SCA effect for grain yield and a highly significant negative SCA effect for days to heading under both sowing dates. These results are in agreement with those obtained by Ali (2006), Ahmed and Mohamed (2009a), Hassan (2015) and Ali et al. (2020). 
Table 4. General (GCA) and specific (SCA) combining ability effects for days to $50 \%$ heading, plant height, 100-grain weight, and grain yield plant ${ }^{-1}$ of the parents and their $\mathrm{F}_{1}$ 's under normal $(\mathrm{N})$ and late $(\mathrm{L})$ planting dates

\begin{tabular}{|c|c|c|c|c|c|c|c|c|}
\hline \multirow[t]{2}{*}{ Genotypes } & \multicolumn{2}{|c|}{ Days to heading } & \multicolumn{2}{|c|}{$\begin{array}{l}\text { Plant } \\
\text { height }\end{array}$} & \multicolumn{2}{|c|}{ 100-grain weight } & \multicolumn{2}{|c|}{$\begin{array}{l}\text { Grain } \\
\text { Yield plant }^{-1}\end{array}$} \\
\hline & $\mathrm{N}$ & $\mathrm{L}$ & $\mathrm{N}$ & $\mathrm{L}$ & $\mathrm{N}$ & $\mathrm{L}$ & $\mathrm{N}$ & $\mathrm{L}$ \\
\hline $\mathrm{P}_{1}$ & 0.50 & -0.56 & 0.41 & 0.79 & $0.14^{*}$ & 0.11 & $-1.56^{* *}$ & 0.24 \\
\hline $\mathrm{P}_{2}$ & $1.98^{* *}$ & $1.92^{* *}$ & $2.57^{* *}$ & $3.99^{* *}$ & 0.06 & $-0.15^{* *}$ & $1.53^{* *}$ & $0.80^{*}$ \\
\hline $\mathrm{P}_{3}$ & $0.72^{*}$ & 1.03 & $1.40^{* *}$ & 0.68 & $-0.31^{* *}$ & $-0.14^{*}$ & $2.31^{* *}$ & -0.39 \\
\hline $\mathrm{P}_{4}$ & $2.43^{* *}$ & $1.85^{* *}$ & $0.88^{*}$ & $1.03^{*}$ & 0.10 & 0.04 & $2.15^{* *}$ & $1.24^{* *}$ \\
\hline $\mathrm{P}_{5}$ & $-4.02^{* *}$ & $-2.34^{* *}$ & $-2.39^{* *}$ & $-2.65^{* *}$ & $-0.20^{* *}$ & -0.04 & $-1.63^{* *}$ & $-1.07^{* *}$ \\
\hline $\mathrm{P}_{6}$ & $0.91^{*}$ & -0.01 & -0.44 & $-1.21^{* *}$ & 0.10 & -0.08 & $-1.20^{*}$ & -0.32 \\
\hline $\mathrm{P}_{7}$ & $-2.53^{* *}$ & $-1.89^{* *}$ & $-2.43^{* *}$ & $-2.63^{* *}$ & 0.10 & $0.26^{* *}$ & $-1.61^{* *}$ & -0.50 \\
\hline $\mathrm{P}_{1} \times \mathrm{P}_{2}$ & $2.70^{* *}$ & $2.77^{*}$ & -0.55 & -0.99 & 0.12 & $0.25^{*}$ & -0.64 & $4.26^{* *}$ \\
\hline $\mathrm{P}_{1} \times \mathrm{P}_{3}$ & 0.96 & -0.60 & $-2.22^{* *}$ & $4.16^{* *}$ & 0.16 & -0.10 & 0.37 & $1.45^{*}$ \\
\hline $\mathrm{P}_{1} \times \mathrm{P}_{4}$ & $1.59^{*}$ & $2.58^{*}$ & -0.20 & 0.88 & -0.25 & $-0.27^{*}$ & 0.90 & $-2.28^{* *}$ \\
\hline $\mathrm{P}_{1} \times \mathrm{P}_{5}$ & $-6.30^{* *}$ & $-9.56^{* *}$ & $3.58^{* *}$ & $2.32^{*}$ & 0.05 & 0.14 & 0.42 & $3.40^{* *}$ \\
\hline $\mathrm{P}_{1} \times \mathrm{P}_{6}$ & 0.78 & 1.18 & -0.62 & 1.88 & $0.42^{*}$ & 0.17 & 0.02 & $-3.76^{* *}$ \\
\hline $\mathrm{P}_{1} \times \mathrm{P}_{7}$ & $-6.78^{* *}$ & $-9.01^{* *}$ & 1.12 & -1.19 & 0.08 & -0.16 & 0.90 & -0.57 \\
\hline $\mathrm{P}_{2} \times \mathrm{P}_{3}$ & 0.48 & -1.82 & 0.63 & $2.69^{* *}$ & $0.90^{* *}$ & $0.49^{* *}$ & $3.65^{* *}$ & $-2.11^{* *}$ \\
\hline $\mathrm{P}_{2} \times \mathrm{P}_{4}$ & 0.11 & -1.64 & -0.02 & 1.42 & 0.16 & $-0.35^{* *}$ & 0.31 & -1.07 \\
\hline $\mathrm{P}_{2} \times \mathrm{P}_{5}$ & $-1.78^{*}$ & $-7.79^{* *}$ & 0.09 & $3.03^{* *}$ & 0.12 & $-0.27^{*}$ & -0.10 & -1.23 \\
\hline $\mathrm{P}_{2} \times \mathrm{P}_{6}$ & $-2.70^{* *}$ & 1.29 & $2.14^{* *}$ & $4.08^{* *}$ & $-0.51^{* *}$ & 0.10 & $4.26^{* *}$ & -0.55 \\
\hline $\mathrm{P}_{2} \times \mathrm{P}_{7}$ & $-3.93^{* *}$ & $-6.56^{* *}$ & $2.13^{* *}$ & $2.21^{*}$ & $0.79^{* * *}$ & $0.91^{* *}$ & $2.04^{*}$ & $3.06^{* *}$ \\
\hline $\mathrm{P}_{3} \times \mathrm{P}_{4}$ & 1.04 & $-2.68^{*}$ & 0.15 & -0.10 & 0.19 & $0.31^{*}$ & 1.39 & -0.05 \\
\hline $\mathrm{P}_{3} \times \mathrm{P}_{5}$ & $-1.52^{*}$ & 1.18 & $2.09^{*}$ & $-2.32^{*}$ & $-0.84^{* *}$ & 0.05 & 0.14 & -0.80 \\
\hline $\mathrm{P}_{3} \times \mathrm{P}_{6}$ & -0.11 & -1.42 & 0.64 & -1.77 & $0.53^{* *}$ & $0.75^{* *}$ & $5.44^{* *}$ & -1.03 \\
\hline $\mathrm{P}_{3} \times \mathrm{P}_{7}$ & $-3.00^{* *}$ & $3.06^{* *}$ & -1.54 & $-2.01^{*}$ & $0.53^{* *}$ & $-0.25^{*}$ & 1.46 & $-2.88^{* *}$ \\
\hline $\mathrm{P}_{4} \times \mathrm{P}_{5}$ & $-2.89^{* *}$ & 1.36 & $2.78^{* *}$ & -1.60 & 0.08 & -0.12 & $4.74^{* *}$ & 0.54 \\
\hline $\mathrm{P}_{4} \times \mathrm{P}_{6}$ & $-1.81^{*}$ & -1.23 & $-3.18^{* *}$ & -1.05 & 0.12 & -0.09 & $-2.86^{* *}$ & $-3.25^{* *}$ \\
\hline $\mathrm{P}_{4} \times \mathrm{P}_{7}$ & 1.30 & 1.92 & $1.81^{*}$ & -0.66 & 0.16 & 0.10 & 1.95 & -0.60 \\
\hline $\mathrm{P}_{5} \times \mathrm{P}_{6}$ & $3.63^{* * *}$ & 1.62 & 1.43 & $2.56^{*}$ & $0.42^{*}$ & -0.01 & $-2.38^{*}$ & 1.09 \\
\hline $\mathrm{P}_{5} \times \mathrm{P}_{7}$ & $7.07^{* * *}$ & $4.10^{* *}$ & $6.59^{* *}$ & $7.99^{* * *}$ & $1.08^{* *}$ & $0.99^{* *}$ & -0.60 & $-2.56^{* *}$ \\
\hline $\mathrm{P}_{6} \times \mathrm{P}_{7}$ & $3.48^{* *}$ & -0.16 & $3.97^{* *}$ & $2.38^{*}$ & $-0.55^{* *}$ & $-0.31^{*}$ & -1.20 & -0.98 \\
\hline S.E. gi & 0.36 & 0.59 & 0.37 & 0.47 & 0.07 & 0.06 & 0.47 & 0.33 \\
\hline S.E. sij & 0.77 & 1.28 & 0.82 & 1.01 & 0.17 & 0.13 & 1.01 & 0.71 \\
\hline S.E. (gi-gj) & 0.40 & 0.64 & 0.43 & 0.53 & 0.10 & 0.07 & 0.53 & 0.37 \\
\hline S.E. (sij-sik) & 1.14 & 1.90 & 1.22 & 1.50 & 0.24 & 0.20 & 1.50 & 1.05 \\
\hline
\end{tabular}

*and **: significant at 0.05 and 0.01 levels of probability, respectively.

\section{C-Heterosis:}

Desirable (negative and significant) better parent heterosis was observed for days to heading in some hybrids under normal and late sowing dates (Table 5), showing earlier heading than the earlierparent at both sowing dates. Under normaland late sowing dates, better parent heterosis ranged from -10.67 and -18.5 to 7.63 and $0.63 \%$, respectively. $\mathrm{P}_{1} \times \mathrm{P}_{5}$, 
Table 5. Percentages of better parent (BP) heterosis for days to heading, plant height, 100-grain weight, and grain yield/plant of $21 \mathrm{~F}_{1}$-crosses under normal(N) and late $(\mathrm{L})$ planting dates

\begin{tabular}{|c|c|c|c|c|c|c|c|c|}
\hline \multirow{2}{*}{ Genotypes } & \multicolumn{2}{|c|}{ Days to heading } & \multicolumn{2}{|c|}{ Plant height } & \multicolumn{2}{|c|}{ 100-grain weight } & \multicolumn{2}{|c|}{ Grain yield plant $^{-1}$} \\
\hline & $\mathrm{N}$ & $\mathrm{L}$ & $\mathrm{N}$ & $\mathrm{L}$ & $\mathrm{N}$ & $\mathrm{L}$ & $\mathrm{N}$ & $\mathrm{L}$ \\
\hline $\mathrm{P}_{1} \times \mathrm{P}_{2}$ & -0.37 & $-4.59^{*}$ & -0.49 & 0.87 & 6.60 & 0.00 & 5.47 & $24.32^{* *}$ \\
\hline $\mathrm{P}_{1} \times \mathrm{P}_{3}$ & -1.52 & $-5.31^{*}$ & $-3.15^{*}$ & $5.17^{* *}$ & 0.00 & $-11.42^{*}$ & 12.73 & 2.08 \\
\hline $\mathrm{P}_{1} \times \mathrm{P}_{4}$ & -0.37 & -0.62 & 0.00 & 1.95 & 0.00 & -8.25 & 2.10 & $-16.90^{*}$ \\
\hline $\mathrm{P}_{1} \times \mathrm{P}_{5}$ & $-10.44^{* *}$ & $-18.58^{* *}$ & 1.46 & 2.79 & 0.00 & 0.00 & 7.14 & $45.72^{* *}$ \\
\hline $\mathrm{P}_{1} \times \mathrm{P}_{6}$ & -0.19 & -2.04 & -0.91 & $4.13^{*}$ & $13.40^{*}$ & 0.00 & 6.81 & $-33.97^{* *}$ \\
\hline $\mathrm{P}_{1} \times \mathrm{P}_{7}$ & $-10.67^{* *}$ & $-17.33^{* *}$ & -1.33 & -1.42 & 7.91 & 0.00 & 10.44 & -6.63 \\
\hline $\mathrm{P}_{2} \times \mathrm{P}_{3}$ & -1.50 & $-7.07^{* *}$ & 1.62 & $4.43^{* *}$ & $27.25^{* *}$ & $23.18^{* *}$ & $42.27^{* *}$ & $-21.08^{* *}$ \\
\hline $\mathrm{P}_{2} \times \mathrm{P}_{4}$ & -1.48 & $-6.04^{* *}$ & 0.49 & 3.17 & $14.13^{*}$ & -9.26 & 11.97 & $-13.27^{*}$ \\
\hline $\mathrm{P}_{2} \times \mathrm{P}_{5}$ & $-4.36^{* *}$ & $-16.53^{* *}$ & $-2.93^{*}$ & 1.45 & 7.91 & 0.00 & 7.99 & $-29.07^{* *}$ \\
\hline $\mathrm{P}_{2} \times \mathrm{P}_{6}$ & $-3.62^{* *}$ & -2.22 & 1.42 & $4.24^{*}$ & 0.00 & 10.21 & $32.98^{* * *}$ & $-19.33^{* *}$ \\
\hline $\mathrm{P}_{2} \times \mathrm{P}_{7}$ & $-6.64^{* *}$ & $-14.46^{* *}$ & -0.67 & -2.97 & $15.83^{*}$ & 8.99 & $20.82^{* *}$ & $-15.48^{*}$ \\
\hline $\mathrm{P}_{3} \times \mathrm{P}_{4}$ & 0.38 & $-3.92^{*}$ & -0.48 & 0.42 & 8.99 & $11.42^{*}$ & $22.16^{* *}$ & -12.74 \\
\hline $\mathrm{P}_{3} \times \mathrm{P}_{5}$ & $-3.25^{*}$ & -1.91 & $15.99^{* *}$ & $-6.42^{* *}$ & -11.99 & 10.21 & 13.00 & $-32.38^{* *}$ \\
\hline $\mathrm{P}_{3} \times \mathrm{P}_{6}$ & 0.19 & -2.07 & -1.32 & $-3.78^{*}$ & 6.60 & $30.03^{* *}$ & $42.77^{* * *}$ & $-28.16^{* *}$ \\
\hline $\mathrm{P}_{3} \times \mathrm{P}_{7}$ & $-4.40^{* *}$ & 0.63 & $-6.11^{* *}$ & $-5.93^{* *}$ & $27.82^{* * *}$ & 0.00 & $21.38^{* * *}$ & $-34.34^{* *}$ \\
\hline $\mathrm{P}_{4} \times \mathrm{P}_{5}$ & $-4.40^{* *}$ & -0.85 & 0.23 & $-5.33^{* * *}$ & 7.91 & 0.00 & $22.22^{* * *}$ & $-17.73^{* *}$ \\
\hline $\mathrm{P}_{4} \times \mathrm{P}_{6}$ & -1.34 & -1.03 & $-3.85^{* *}$ & -2.75 & 6.60 & 0.00 & $-15.71^{*}$ & $-28.16^{* *}$ \\
\hline $\mathrm{P}_{4} \times \mathrm{P}_{7}$ & 0.79 & 0.42 & -0.89 & -1.07 & $31.89^{* *}$ & $36.24^{* *}$ & 7.94 & 4.82 \\
\hline $\mathrm{P}_{5} \times \mathrm{P}_{6}$ & $4.74^{* * *}$ & -0.21 & 1.91 & $6.42^{* *}$ & 7.91 & 10.21 & -6.23 & $-30.07^{* *}$ \\
\hline $\mathrm{P}_{5} \times \mathrm{P}_{7}$ & $7.63^{* * *}$ & 0.43 & $15.43^{* *}$ & $14.79^{* *}$ & $43.88^{* * *}$ & $39.94^{* *}$ & 2.82 & $-41.63^{* *}$ \\
\hline $\mathrm{P}_{6} \times \mathrm{P}_{7}$ & $4.67^{* *}$ & -1.91 & $4.67^{* *}$ & $6.05^{* *}$ & -7.91 & 0.00 & 0.17 & $-32.53^{* *}$ \\
\hline
\end{tabular}

*,**: Significant at 0.05 and 0.01 levels of probability, respectively.

$\mathrm{P}_{1} \times \mathrm{P}_{7}, \mathrm{P}_{2} \times \mathrm{P}_{5}$, and $\mathrm{P}_{2} \times \mathrm{P}_{7}$ expressed desirable (negative and highly significant) earliest better parent heterosis for days to heading in early and late sowing date as it could be expected from SCA effects.

Positive and highly significant better parent heterosis was observed for some hybrids for plant height in both dates (Table 5). The hybrids $\mathrm{P}_{5} \times \mathrm{P}_{7}$ and $\mathrm{P}_{6} \times \mathrm{P}_{7}$ were the tallest better parent heterosis under both sowing dates. The range of better parent heterosis for plant height was wide between -6.11 and $15.99 \%$ at a normal date and -6.42 and $14.79 \%$ at a late date.

Desirable (positive and highly significant) better parent heterosis was observed for 100-grain weight by some hybrids (Table 5). Better parent heterosis ranged from -11.9 to $43.88 \%$ and from 11.42 to $39.94 \%$ under normal and late sowing dates. Three crosses, $\mathrm{P}_{2} \times \mathrm{P}_{3}, \mathrm{P}_{4} \times$ $\mathrm{P}_{7}$, and $\mathrm{P}_{5} \times \mathrm{P}_{7}$, had positive and heaviest grain weight and better parent heterotic values under both sowing dates.

The degree of better parent heterosis differed among hybrids in grain yield. Some hybrids grown in early and late sowing dates showed useful better parent heterosis, indicating the superior grain yield performance compared to the better parent. The range of better parent heterosis was wide between - $15.71\left(\mathrm{P}_{4} \times \mathrm{P}_{6}\right)$ and 42.77 $\%\left(\mathrm{P}_{3} \times \mathrm{P}_{6}\right)$ at the normal date. It ranged from -41.63 and $45.72 \%$ under late date, 
recorded by $\mathrm{P}_{5} \times \mathrm{P}_{7}$ and $\mathrm{P}_{1} \times \mathrm{P}_{5}$, respectively. These results are in harmony with those obtained by Ahmed and Mohamed (2009b), Hassan (2015), and Ali et al. (2020).

\section{References}

Ahmed, M. S. H., and Mohamed, S. M. S. (2009a)' Diallel crosses of bread wheat (Triticum aestivum L.) at two sowing dates 1 . Genetic analysis of yield and its components', Egypt. J. Plant Breed. 13: pp. $281-301$.

Ahmed, M. S. H. and Mohamed,S. M. S. (2009b) 'Diallel crosses of bread wheat (Triticum aestivum L.) at two sowing dates 2. Heterosis, correlation and path analysis among some yield components' Egypt. J. Plant Breed. 13: pp. 303 - 318.

Ahmed, N., Khan A. S., Kashif, M., and Rehman, A. (2017) 'Genetic studies of biomass partitioning in wheat under water stress conditions' The J. of Animal plant sciences, 27: pp. 144 - 152.

Ahmadi, J., Zali, A. A., Yazdi, S. B., Talaie, A., Ghannadha, M. R. and Saeidi, A. (2003)' A study of combining ability and gene effect in bread wheat under drought stress condition by diallel method' Iranian J. of Agric. Sci., 34 (1): pp. 1 - 8. (C.F. ComputerInter. Agric. Cent. for Information Service).

Ali, M. A. (2006) 'Combining ability and stability analysis in spring wheat under four soil available water levels,'Assiut J. of Agric. Sci., 37(4): pp. 95 - 118.

M. Ali, M. A., Hassan, M. S. and Ali, I. A. (2020) 'Combining ability in some genotypes of bread wheat (Triticum aestivum L.) under different sowing dates,' SVU-International J. of Agric. Sci., Volume 2 Issue (2): pp. 291 - 305.
Bahatt, G. M. (1971)'Heterotic performance and combining ability in diallel cross among spring wheat (Triticum aestivumL.), 'Aust J. Agric. Res., 22: 3pp. 59 - 368.

Bajaniya, N., Pansuriga, A. G. Vekaria, D. M., Singh C. and Savaliga, J. J. (2019) 'Combining ability for grain yield and its components in durum wheat (Triticum durum Desf.)' Ind. J. Pure App. Biosci., 7: pp. 217 - 224.

Barot, H. G., Patel, M. S., Sheikh, W. A., Patel, L. P. and Allam, C. R. (2014)' Heterosis and combining ability analysis for yield and its component traits in wheat (Triticum aestivum L.)' Elec. J. Pl. Br., 5(3): pp. 350 - 359.

Darwish, I. H. I., El-Sayed, E., and Waffa, El-Awady (2006) 'Genetical studies of heading date and some agronomic characters in wheat' Annals of Agric. Sci. Moshtohor, 44(2): pp. 427 - 452.

Dencic, S., Kastori, R., Kobiljski, B. and Duggan, B. (2000) 'Evaluation of grain yield and its components in wheat cultivars and landraces under nearoptimal and drought conditions,' Euphytica 113: pp. 43 - 52.

Dhadhal, B. A. and Dobariya, K. L. (2006) 'Combining ability analysis over environments for grain yield and its components in bread wheat (Triticum aestivum L.),'National. J. Pl. Improv., 8, 172 - 173.

El-Beially, I. E. M. A. and El-Sayed,E. A. M.. (2002) 'Heterosis and combining ability for some bread wheat cross' J. Agric. Sci. Mansoura Univ., 27(9): pp. 5735 5744. 
El-Rawi, K. and Khalafalla1, A. M. (1980)

'Design and analysis of agricultural experiments' El Mousel Univ., Iraq, 19.

Ezatollah, F.'Rafiee,F., and Hasheminasab, H. (2013) 'Evaluation of genetic parameters of agronomic and morpho-physiological indicators of drought tolerance in bread wheat (Triticum aestivum L.) using diallel mating design' Australian J. of Crop Sci., 7 (2): pp. 268 - 275.

Falconer, D. S. (1990) 'Selection in a different environment affects environmental sensitivity (reaction norm) and mean performance' Genre. Res. Camb., 56: pp. 57 - 70.

FAO (2018) 'Food and Agriculture Organization of United Nations' Vial DelleTerme di Caracalla, 00100. Rome, Italy. Fisher, R. A., and Maurer, R. O. (1978) 'Drought resistance in spring wheat cultivars. 1- Grain yield responses', Aust. J. Agric. Res.; 29: pp. 897-912.

Fisher, R. A. and R. O. Maurer. 1978. Drought resistance in spring wheat cultivars. 1- Grain yield responses. Aust. J. Agric. Res.; 29: pp. 897 912.

Gomez, K. A., and Gomez, A. A. (1984) 'Statistical Procedures for Agricultural Research' John Wiley \& Sons Inc. New York, USA.

Gribson, L. R. and Paulsen, G. M. (1999) 'Yield components of wheat grown under high-temperature stress during reproductive growth' Crop Sci.; 39 (6): pp. $1841-1846$.

Griffing, B. (1956) 'Concept of general and specific combining ability in relation to diallel crossing systems' Aust. J. Biol. Sci., 9: pp. 463 - 493.
Hassan, M. O. M. (2015) 'Combining ability and genetic components in durum wheat under heat stress conditions in reclaimed soils' M.Sc. Thesis, Fac. of Agric. Assiut Univ., Egypt.

Hassan, M. I. (2016) 'Assessment of genetic diversity in bread wheat genotypes based on heat tolerance and SSR markers' Assiut J. Agric. Sci., 47 (5): pp. $37-55$.

Hoffman, B. and Burucs, Z. (2005) 'Adaptation of wheat (Triticum aestivum L.) genotypes and related species to water deficiency' Cereal Research Comm., 33: pp. 681 - 687.

Jaiswal, B., S., Prasad, R., Dwivedi, S., Singh, R., Shrivastava, R., Kumar, S. A. and Yadav, R. K. (2017) 'Study of yield and yield components of wheat (Triticum aestivum L.) genotypes at grain filling stage under heat regimes' Int. J. Pure App. Biosci., 5(4): pp. 331 340.

Lobell, D. B., Ortiz-Monasterio, IJ., and Asner, GP. (2005) 'Analysis of wheat yield and climatic trends in Mexico' Field Crops Res.; 94: pp. 250 256.

Lohithaswa, H. C., Desai, S. A., Hanchinal, R. R., Patil, B. N., Math, K. K., Kalappanavar, I. K., Bandivadder, T. T. and Chandrashekhara, C. P. (2013) ' Combining ability in tetraploid wheat for yield, yield attributing traits, quality and rust resistance over environments' Karnataka Journal of Agricultural Science, 26(2): pp. 190 - 193. 
Mohamed, M. M. (2007) 'Genetic studies on durum wheat breeding for heat tolerance' M.Sc. Thesis, Faculty of Agric. El-Minia., Univ., Egypt.

Mwadzingeni, L., Shimelis, H. and Tsilo, T. J. (2017) 'Combining ability and gene action controlling yield and yield components in bread wheat (Triticum aestivum L.) under drought-stressed and non-stressed conditions' Plant Breeding, Volume 137, issue 4.

Nassar, S. M. A. M. (2013) 'Genetic variance and combining ability in bread wheat under drought stress conditions' Ph.D. Thesis, Fac. of Agric. Assiut Univ., Egypt.

Pansuriya, A. G., Dhaluk, L. K., Vanpariya, L. G., Savaliya, J. J., Patel, M. B. and Mehta, D. R. (2014) 'Combining ability over environments for grain yield and its components in bread wheat (Triticum aestivum L.)' Int. e. J., 3(1): pp. 36 - 46.

Saini, A. D., Dadhwal, V. K., Phadnawis, B. N. and Nonda, R. (1986) 'Influence of sowing dates on pre-anthesis phenology in wheat' Indian J. of Agric. Sci. 56: pp. 503 - 511.

Samra, J. S. Dhilion, S. S. and Kahlon, P. S. (1989) 'Response of wheat varieties to date of sowing' Indian J. Agron. 34: pp. 286 - 289.
Shah, W. A., Bakht, J., Ullah, T., Khan, A. W., Zubair, M., and Khakwani, A. A. (2006) 'Effect of sowing dates on the yield and yield components of different wheat varieties' Journal of Agronomy, 5 (1): pp. $106-110$.

Sharma, V., Dodiya, N. S., Dubey, R. B., and Khn, R. (2019) 'Combining ability analysis in bread wheat (Triticum aestivum L.) EM. Thell) under different Environmental conditions' Bangladesh J. Bot. 48: pp. 89 - 93.

Sharma, A. K. and Garg, D. K. (2005) 'Combining ability over environments in bread wheat (Triticum aestivum L.)' J. Maharashtra Agric. Univ., 30, pp. 153 - 156.

Singh, K., Singh, U. B. and Sharma, S. N. (2013) 'Combining ability analysis for yield and its components in bread wheat (Triticum aestivum L.)' J. Wheat Res., 5(1): pp. 63 - 67.

Vanpariya, L. G.;V. P. Chovatiaand D. R. Mehta (2006) 'Combining ability studies in bread wheat (Triticum aestivumL.)' National J. $\mathrm{Pl}$. Improv., 8(2): pp. 132-137.

Wajid, A. J., Baloch, M. J., Kumbhar, M. B., Khan, N. U., and Kerio, M. I. (2011) 'Effect of water stress on physiological and yield parameters at anthesis stage in elite spring wheat cultivars' Sarhad J. Agric., 27 (1): pp. 59 65. 